\title{
Organochlorine and Metal Contaminants in the Blood Plasma of Green Sturgeon Caught in Washington Coastal Estuaries
}

Julie Layshock

Pacific University

Molly Webb

US Fish and Wildlife Service

Olaf Langness

Washington Department of Fish and Wildlife

John Carlos Garza

National Marine Fisheries Service

Laura Heironimus

Washington Department of Fish and Wildlife

Deke Gundersen ( $\sim$ deke@pacificu.edu )

Pacific University https://orcid.org/0000-0002-3203-2176

Original Research

Keywords: Organochlorine, Metal Contaminants, Washington Coastal Estuaries

Posted Date: February 4th, 2021

DOI: https://doi.org/10.21203/rs.3.rs-172046/v1

License: () (1) This work is licensed under a Creative Commons Attribution 4.0 International License.

Read Full License

Version of Record: A version of this preprint was published at Archives of Environmental Contamination and Toxicology on October 16th, 2021. See the published version at https://doi.org/10.1007/s00244-02100896-2. 


\section{Abstract}

Non-invasive monitoring was used to evaluate the concentrations of forty contaminants in the blood plasma of the North American Green Sturgeon Acipenser medirostris caught and released from three estuaries in Washington State. The highest contaminant loads were found in fish caught in the most urbanized sites. Few statistical differences were found when evaluating contaminant levels according to sex, maturation stage, or distinct population segments of Green Sturgeon. The results indicate that recent exposure to legacy contaminants was reflected in Green Sturgeon plasma. Aldrin, 4,4-DDE, a-BHC, copper, and selenium were the most frequently detected contaminants. This study also explored the challenges of assessing toxicity in threatened species using non-lethal approaches. There is currently a lack of environmental contaminant monitoring data in estuaries frequented by Green Sturgeon and limited plasma to tissue toxicity correlations.

\section{Introduction}

Green Sturgeon are a long-lived, anadromous species, endemic along the west coast of North America. The species consists of two distinct population segments (DPSs) that are genetically differentiated and are defined by the river locations during spawning. The Southern DPS (sDPS), listed as threatened under the US Endangered Species Act (ESA; 71 FR 17757, April 7, 2006) and the Northern DPS (nDPS), identified as a species of concern (Doukakis 2014). The sDPS includes fish that spawn in the Sacramento River, and the nDPS includes those spawning annually in the Rogue, Klamath, and Eel rivers, and those spawning inconsistently in the Umpqua and Columbia rivers (Farr and Kern 2005, Adams et al. 2007, Webb and Erickson 2007, Schreier et al. 2016, Stillwater Sciences and Wiyot Tribe Natural Resources Department 2017, Schreier and Stevens 2020). Green Sturgeon have an extended range off of the North American coast where adults and sub-adults make long-distance annual migrations (Lindley et al. 2008; Lindley et al. 2011; Moser et al. 2016). During the summer, Green Sturgeon will aggregate in estuaries in search of food (Moser and Lindley 2007), particularly the Columbia River estuary, Willapa Bay, and Grays Harbor (Adams et al. 2002; Lindley et al. 2011). These feeding areas have significant anthropogenic activities, potentially exposing sturgeon to a variety of stressors, including fisheries bycatch, increased water temperature, and contaminants (Israel et al. 2009). Gut content studies show that adult and subadult Green Sturgeon feed on a variety of benthic fishes, crustaceans, and bivalves while in these coastal estuaries (Dumbauld et al. 2008). In the Columbia River, Green Sturgeon congregate in the turbidity maximum to feed on these organisms (Langness et al. 2014). In Willapa Bay and Grays Harbor, thousands of pits per hectare indicate intensive sturgeon feeding over unvegetated littoral mud flats during high tide (Moser et al. 2017). This disturbance of the substrate while feeding increases their exposure to sediment-associated contaminants.

One specific threat identified in the sDPS Green Sturgeon Recovery Plan (2017) is the possible exposure to contaminants and the resulting impacts on survival and reproduction. Contaminants may stem from agriculture runoff, urban development, discharge from industries, mining, land-use practices, and the application of chemicals and pesticides to control burrowing shrimp populations (Moser et al. 2016). 
While foraging in estuaries, Green Sturgeon may accumulate contaminants through prey, sediment contact, or direct absorption from the water. Green Sturgeon blood plasma taken from twenty-one fish caught in the Columbia River estuary, Willapa Bay and Grays Harbor during 2003-2005, was previously examined for the presence of 17 organochlorine pesticides (OCs) and polychlorinated biphenyls (PCBs). Low OC concentrations and no PCB detections were recorded. This preliminary work done by Gundersen (Langness 2007) had insufficient samples to determine statistically significant differences between sex, size, or DPS categories. Previous studies have shown contaminants to have deleterious impacts on sturgeon health. Studies looking at White Sturgeon (Acipenser transmontanous), collected from the same areas occupied by Green Sturgeon, have shown a variety of contaminants in tissues at levels that correlated with negative health effects. Levels of selenium, mercury, cadmium, arsenic, and copper exceeded levels shown to impair health in other fish species (Gundersen et al. 2017). Dichlorodiphenyldichloroethylene (DDE), PCBs and methylmercury were frequently detected in White Sturgeon gonad and liver tissues collected from the Columbia river. Levels of these contaminants were negatively correlated with plasma testosterone and 11-ketotestosterone in male White Sturgeon (Feist et al. 2005; Webb et al. 2006). Contaminants have been detected in other fish species in estuaries occupied by Green Sturgeon. A study investigating contaminant levels in juvenile Chinook and Coho salmon collected from a variety of estuaries in the Pacific Northwest, found relatively high whole-body levels of PCBs and DDE were found in fish collected from Grays Harbor and Willapa Bay (Johnson et al. 2007).

Evaluating toxicity from contaminant accumulation typically requires sacrificing the animals, measuring concentrations and biomarkers of effect in several tissues. However, non-lethal methods of contaminant monitoring have now been employed for many species of wildlife, including birds (Elliott and Shutt 1993; Dhananjayan and Muralidharan 2010), snakes (Bishop and Rouse 2000), turtles (Bucchia et al. 2015), and sturgeon (Gundersen et al. 2008; Jacobs et al. 2014). These previous studies demonstrated correlations between blood and tissue concentrations for lipophilic contaminants. In polar bears, PCBs and organochlorine pesticides concentrations in subcutaneous lipid and blood cells were highly correlated (Bernhoft et al. 1997). Other tissue and blood correlations were found between whole blood and fat from sea turtles (Keller et al. 2004) and between blood plasma, fat, and eggs from snapping turtles (Dabrowska et al. 2006) for chlorinated lipophilic contaminants. A study on White Sturgeon found correlations between plasma and liver OC concentrations (Gundersen et al. 2008) and plasma contaminant concentrations were used to evaluate endocrine disruption in a study on Lake Sturgeon Acipenser fulvescens (Jacobs et al. 2014).

The objectives of this work were to use non-lethal methods to evaluate the level of contaminant exposure and to assess if contaminant burden differs in Green Sturgeon across various size, sex, and stage of maturity. Because sub-adult and adult Green Sturgeon of both DPSs aggregate within major coastal estuaries of Washington during the summer months (Moser and Lindley 2007; Moser et al. 2016), this study had a unique opportunity to evaluate contaminant exposure and compare contaminant burden between the ESA-listed SDPS and nDPS Green Sturgeon. 


\section{Materials And Methods}

\section{Fish Sampling}

Green Sturgeon were captured by gill net in Grays Harbor, Willapa Bay, and the Columbia River estuary, Washington (Fig. 1), in June-September of 2011 and 2012 following the protocol in Langness et al. (2014). Before release, the fish were examined for injuries, infections, deformities, condition, and preexisting internal and external tags, with fork length $(\mathrm{FL})$ measured to the nearest $\mathrm{cm}$. If fish were not already tagged, a passive integrated transponder (PIT) tag was applied in accordance with NMFS tagging protocols (Kahn and Morhead 2010). The fish used in this study had $69 \mathrm{kHz}$ VEMCO-coded acoustic transponder tags interperitonially implanted as well. An approximately $1 \mathrm{~cm}^{2}$ section of pectoral fin was removed for genetic analysis and stored in $95 \%$ ethanol solution. Whole blood was drawn from the caudal vein using heparinized Vacutainers. About $1-6 \mathrm{~mL}$ of plasma was separated from the whole blood samples by centrifugation at 5000 RPM for $5 \mathrm{~min}$. Aliquots of plasma were transferred to microcentrifuge tubes and stored frozen for sex steroid and chemical analyses.

Fig.1 Map of North American green sturgeon natal rivers showing the Sacramento River where the Southern Distinct Population Segment (SDPS) sturgeon spawn, and the Klamath and Rogue rivers where the Northern Distinct Population Segment (NDPS) sturgeon primarily spawn. The insert map shows the study area (Grays Harbor, Willapa Bay, and the Columbia River estuary) where the sampled Green Sturgeon were caught and released.

\section{Genetics}

Pectoral fin clips, corresponding to the 131 blood plasma samples used for the contaminant analyses, were subsampled for genetic analysis. Genomic DNA was extracted from all samples with DNeasy 96 blood and tissue kits on a BioRobot 3000 (Qiagen, Inc., Valencia, CA). Discrimination of the nDPS and sDPS was accomplished using genotypes from a set of 74 Single Nucleotide Polymorphism (SNP) markers developed for Green Sturgeon and a juvenile reference dataset from samples of juveniles captured in the Klamath (nDPS) and Sacramento (sDPS) rivers (Anderson et al. 2017). Genotype data was generated using SNP Type allelic discrimination assays in 96.96 Dynamic Arrays on an EP1 system (Fluidigm Corporation, S. San Francisco, CA). Because Green Sturgeon are tetraploid (i.e. have four functional genome copies, not two like most animals), traditional genotype calling methods are not possible. Rather, we used the graphical genotype category and calibration approach of Anderson et al. (2017) to call genotype categories for each individual at each genetic marker. This approach has been shown to identify individuals to the two Green Sturgeon DPSs with 100\% accuracy, even when data quality is poor (Anderson et al. 2017). This SNP assay approach also provide smore accurate identifications than previously described microsatellite methods (Israel et al. 2009, Schreier et al. 2016). 
Steroids (testosterone $[T]$ and estradiol-17 $\beta$ [E2]) were extracted from the plasma $(n=131)$ following the method of Fitzpatrick et al. (1987). Briefly, $100 \mu \mathrm{L}$ of plasma was extracted twice with $2 \mathrm{~mL}$ of diethyl ether. Tubes were vortexed vigorously with ether, and the aqueous phase removed by snap-freezing in liquid nitrogen. Ether was allowed to evaporate overnight. The extracted steroids were resuspended in 1 $\mathrm{mL}$ of phosphate-buffered saline with gelatin (PBSG), and 10 or $50 \mu \mathrm{L}$ was assayed for each steroid. Recovery efficiencies for all steroids were determined by adding tritiated steroids to tubes containing plasma $(n=4)$, which was extracted as described above. Recovery efficiencies were $91-98 \%$ for testosterone $(T)$ and $83-96 \%$ for estradiol-17 $\beta$ (E2). All steroid assay results were corrected for recovery.

Steroids ( $T$ and E2) were measured by radioimmunoassay (RIA) as described by Fitzpatrick et al. (1986) and modified by Feist et al. (1990). All samples were analyzed in duplicate. Steroid levels were validated by verifying serial dilutions were parallel to standard curves. A slightly more concentrated charcoal solution ( $6.25 \mathrm{~g}$ charcoal and $4.0 \mathrm{~g}$ dextran $\mathrm{L}^{-1}$ PBSG) was used for all assays to reduce non-specific binding. The intra- and inter-assay coefficients of variation for all assays were less than $5 \%$. Quantified plasma sex steroid concentrations below the minimum quantifiable concentration (MQC) of the RIA were assigned the MQC $\left(0.40 \mathrm{ng} \mathrm{mL}^{-1}\right.$ for T and $0.20 \mathrm{ng} \mathrm{mL}^{-1}$ for E2).

Sex and stage of maturity were assigned according to plasma T and E2 concentrations as no gonadal tissue sampling was possible during 2011 and 2012. Sex and stage of maturity assignments based on plasma sex steroid concentrations correspond well with assignments based on histology of gonad tissue (Webb and Talbott 2007; Webb and Erickson 2007). Fish with plasma concentrations of 4-19 $\mathrm{ng} \mathrm{mL}^{-1} \mathrm{~T}$ and E2 concentrations less than $1 \mathrm{ng} \mathrm{mL}^{-1}$ were assigned as non-reproductive males (pre-meiotic), while fish with less than $4 \mathrm{ng} \mathrm{mL}^{-1} \mathrm{~T}$ and E2 concentrations less than $1 \mathrm{ng} \mathrm{mL}^{-1}$ were assigned as nonreproductive females (pre-vitellogenic). Fish were assigned as spawning-capable males (meiotic) if plasma T concentrations were greater than $20 \mathrm{ng} \mathrm{mL}^{-1}$ and E2 concentrations were less than $1 \mathrm{ng} \mathrm{mL}^{-1}$ and vitellogenic or spawning-capable females if plasma T concentrations were greater than $10 \mathrm{ng} \mathrm{mL}^{-1}$ and E2 concentrations were greater than $1 \mathrm{ng} \mathrm{mL}^{-1}$.

\section{Contaminant analysis}

Plasma samples were stored at $0^{\circ} \mathrm{C}$ until analysis. A total of 131 blood plasma samples were analyzed for metals, and 128 samples were analyzed for OCs. All reagents were trace analytical grade including hexanes (Sigma-Aldrich GC residue analysis, $>98.5 \%$ purity), sodium sulfate (Sigma-Aldrich, $>99 \%$ purity), and nitric acid (Aristar Plus $>99.999 \%$ purity). For metals analysis, ultra-high purity (UHP) water (18 M $\Omega$ ) from an Elga water purification system was used to prepare all standards and samples. A stock standard of 10 metals, plus an internal standard (yttrium) was prepared from individual metal standards (SigmaAldrich Trace-cert ${ }^{\circledR}>99.999 \%$ purity) in $2 \%$ wt./wt. nitric acid. Metals calibration solutions were prepared in $2 \%$ wt./wt. UHP nitric acid in concentrations ranging from 0.1 to $5000 \mathrm{ppb}$ with $0.2 \mathrm{ppm}$ of the internal standard, yttrium. All metals standard solutions were stored in plastic containers at room temperature. A

mix of 18 organochlorine pesticides (Accustandard Z-1014C, $2 \mathrm{mg} \mathrm{mL}^{-1}$ ) and three mixes consisting of 
16 polychlorinated biphenyls (Accustandard PCB C-SCA-01, -02, and -03) were combined into one analytical standard along with two surrogate recovery standards, decachlorobiphenyl and tetrachloroxylene (Restek 3253, 1000 ppm). Calibration solutions were prepared in hexanes at concentrations ranging from 0.1 to $1000 \mathrm{ng} \mathrm{mL}^{-1}$. All organic standard solutions were stored in glassware at $4^{\circ} \mathrm{C}$. A list of analytes included for chemical analysis can be found in Table S1.

For metals, 300 microliters of equilibrated and vortexed plasma were digested at $60^{\circ} \mathrm{C}$ for 1 hour in $35 \%$ wt./wt. UHP nitric acid. Samples were then spiked with the internal standard, diluted to $6.0 \mathrm{~mL}$ using UHP water, and filtered through a 0.45 -micron PTFE syringe filter. For organic analysis, 0.5 to $3 \mathrm{~mL}$ of plasma was spiked with recovery surrogate standards (50 $\mu \mathrm{L}$ of a $1000 \mathrm{ppm}$ standard), added to $8.0 \mathrm{~mL}$ of hexanes, and placed on a tube rotator at $50 \mathrm{rpm}$ for two hours. The organic layer was removed, dried with sodium sulfate, filtered through at 0.45 -micron syringe filter, and concentrated using $\mathrm{N}_{2}$ gas (Turbovap LV, Biotage) to a final volume of $0.50 \mathrm{~mL}$.

An Agilent 5100 Inductively Coupled Plasma - Atomic Emission Spectrometer (ICP-AES) with a 94.74 lines/mm echelle grating and prism with Charged Coupled Device (CCD) detector was used for metals analysis. OC pesticides and PCBs were analyzed using a Shimadzu 2014 GC equipped with a chlorinesensitive Electron Capture Detector (ECD) and a $30 \mathrm{~m}$ SPB 0608 column $(0.25 \mathrm{~mm}, 0.25 \mu \mathrm{m})$. The GC used nitrogen for the makeup gas and helium at $1.5 \mathrm{~mL} / \mathrm{min}$ as the carrier gas. The separation program was as follows: $150^{\circ} \mathrm{C}, 4 \mathrm{~min}$ hold, ramp at $8^{\circ} \mathrm{C} / \mathrm{min}$ to $290^{\circ} \mathrm{C}$, followed by a $10 \mathrm{~min}$ hold.

\section{Quality control for contaminants analysis}

Numerous procedures were used to limit laboratory contamination of the samples, including the use of high-quality standards and reagents and using plastic-ware for metals analysis and baked glassware $\left(450^{\circ} \mathrm{C}\right.$ for 4 hours) for the organics analysis. Metals were identified using characteristic emission wavelengths and quantified using an internal standard method of calibration with 7-point calibration curves having $R^{2}>0.995$. OCs and PCBs were identified by retention times (RT) established with authentic standards. Analytes were quantified using surrogate-recoveries and 8-point calibration curves having $R^{2}>0.995$. Method detection limits (MDLs) were calculated from the standard deviations (SDs) at the $99 \%$ confidence level for $\mathrm{n}=7$ low concentration spikes $\left(15 \mathrm{ng} \mathrm{mL}^{-1}\right.$ for metals and $0.2 \mathrm{ng} \mathrm{mL}^{-1}$ for organics). Individual MDLs can be found in Table S1. Average analyte recoveries from the calibration verification standards for OCs were $102+/-8 \%(n=10)$ and $98.6+/-0.6 \%(n=2)$ for metal recoveries.

Each batch (15 to 20 samples) consisted of at least two negative controls, matrix-matched method blanks and reagent blanks. Organochlorines detected in method $(n=10)$ and reagent blanks $(n=12)$ were below method detection limits, with the exception of $\delta-B H C$, which was detected at an average concentration of $2.8 \mathrm{ng} \mathrm{mL}^{-1}$ in method blanks. As such, all samples were method blank-subtracted to account for $\delta$-BHC. There was spectral interference for arsenic in method blanks ( $n=4$, Table S2). Arsenic was only reported in plasma samples where the concentration in the sample was 10 times the method blank. Positive controls included either a laboratory control sample (LCS), or a matrix spike (MS). The LCS 
recoveries of metals $(n=2)$ averaged $103+/-3 \%$ (with SD). Recoveries (with SD) from MS samples were between $101+/-18 \%, n=8$ for OCs and $95.2+/-9 \%, n=5$, for metals. Duplicate plasma samples were included to assess precision, $n=5$. The average relative percent difference (RPD) ranged from 4 to $38 \%$ for most individual analytes. However, for some OCs detected close to the MDLs, RPDs were $200 \%$, indicating that an analyte was detected in one sample, but not the duplicate. This result is unsurprising given that samples sizes varied. The RPD for copper and selenium were $4 \%$ and $10 \%$, respectively. Quality control sample data can be found in Tables S3 and S4.

\section{Statistical analysis}

Concentrations less than the MDL for contaminants analysis were considered non-detections for totaling and summations. For other statistical purposes, a value of $1 / 2 \mathrm{MDL}$ was substituted for non-detections on analytes with a detection frequency greater than $60 \%$. In most cases, parametric statistical tests were used, despite normality test failures using the Shapiro-Wilk test, because of large sample sizes. Differences amongst groups were compared using Student's t-tests and one-way Analysis of Variance (ANOVA). For $\mathrm{t}$-tests comparing groups with fewer than 30 samples, nonparametric rank-sum methods using medians were applied. Correlations were tested using Pearson Product Moment Correlation. All statistics were performed using SigmaPlot 14.0.

\section{Results And Discussion}

Little is known about contaminant accumulation in the Green Sturgeon of the Pacific Northwest or about the influence that contaminants have on the decline of the species. The objectives of this study were to determine $\mathrm{OC}, \mathrm{PCB}$, and metal accumulation in the fish using non-lethal monitoring methods. Additional aims were to determine if there were differences in contaminant loads based on sex, location, or DPS. Because sDPS Green Sturgeon are ESA-listed, an additional aim was to address toxicity implications. Fin clips and blood plasma were collected from 131 individual Green Sturgeon that were caught and released from three locations in the Pacific Northwest (Columbia River, Willapa Bay, and Grays Harbor) during 2011 to 2012. Fish from both of the genetically distinct population segments of Green Sturgeon were studied, including 69 from the nDPS and 62 from the sDPS. Of these fish, 24 were assigned as male and 98 were assigned as female; nine fish were not assigned a sex due to insufficient sample volume. Five males and four females were spawning capable, while all others were in a non-reproductive gametogenic phase. The fork length ranged from 84 to $199 \mathrm{~cm}$ and averaged $127+/-24$ (SD) cm. Females over 132 $\mathrm{cm}$ fork length and males over $109 \mathrm{~cm}$ fork length were considered as adults according to Nakamoto et al. (1995). Given this information, the sex-assigned samples consisted of 67 sub-adults and 55 adult fish.

\section{Contaminants in Green Sturgeon plasma}

Metals were detected in $100 \%$ of Green Sturgeon plasma samples $(n=131)$. Copper and selenium were the most abundant metals with detection frequencies of $97 \%$ and $52 \%$, respectively. Average (with SD) copper plasma concentrations were $270+/-303 \mathrm{ng} \mathrm{mL}^{-1}(\mathrm{n}=126)$, while selenium concentrations were 
$227+/-57 \mathrm{ng} \mathrm{mL}^{-1}(\mathrm{n}=76)$. The highest copper concentration (3390 $\left.\mathrm{ng} \mathrm{mL}^{-1}\right)$ was found in plasma from a female nDPS fish from Willapa Bay. Other metals, lead and arsenic, were found in less than ten plasma samples, Fig. 2a.

Fig. 2 Distribution plots showing the range of concentrations and number of detections for a) metals, b) organochlorine pesticides, and c) polychlorinated biphenyls detected in the North American Green Sturgeon blood plasma. Boxes represent the $25^{\text {th }}$ to $75^{\text {th }}$ quartiles with the median shown as a horizontal line and outliers as dots

It was expected that copper and selenium would have the highest detection frequencies given that they are essential for biological function. However, the detections are significant since both metals may be harmful to sturgeon at certain concentrations (Vardy et al. 2015; Linares-Casenave et al. 2015). A similar non-invasive monitoring study on sea turtles reported comparable concentrations of copper $(1020+/-99$ $\mathrm{ng} \mathrm{mL} \mathrm{m}^{-1}$ ) and selenium (2447 +/- $631 \mathrm{ng} \mathrm{mL}^{-1}$ ) in blood (Van De Merwe et al. 2010). This sea turtle study also observed correlations between tissue and blood concentrations for many metals, including selenium, but not copper. Plasma concentrations of metals have not previously been reported in sturgeon, but other studies have reported copper and selenium accumulation in the liver and gonads (Gundersen et al. 2017). It remains unclear how plasma concentrations of metals might correlate to accumulated metal concentrations in tissue of sturgeon.

OCs were detected in $94 \%(n=120)$ of the 128 plasma samples analyzed. The most frequently detected OCs were pesticides (aldrin, a-BHC, $y-B H C, 4,4^{\prime}-D D E$, and endrin), Fig. 2b. Additional pesticides were detected in 25 or fewer samples and included heptachlor, 8 -BHC, dieldrin, endosulfan II, endosulfan sulfate, and methoxychlor. The median $\mathrm{OC}$ concentrations were near the analytical MDLs; however, the concentrations were wide-ranging for several pesticides. The highest contaminant concentrations detected in the plasma were of endosulfan II from two fish, a sDPS male from the Columbia River and a sDPS female from Willapa Bay. A sDPS female fish caught in Grays Harbor had the highest 4,4-DDE concentrations. Total OC pesticides $\left(\sum_{16}\right.$ Pest) were low, averaging $5.5+/-5.5 \mathrm{ng} \mathrm{mL}^{-1}$. The highest $\sum_{16}$ Pest concentration ( $48.5 \mathrm{ng} \mathrm{mL}^{-1}$ ) was influenced by anomalous concentration of endosulfan II. PCBs were infrequently detected and found in 15 or less plasma samples, Fig. 2c. Detected PCBs included PCB99, PCB153, PCB180, and PCB194. The OC contaminants found in Green Sturgeon plasma have been banned since 1979 in the United States. They are still used by other countries and the environmental re-distribution, prevalence, persistence, and bioaccumulation potential of these lipophilic chemicals have been well documented (Tanabe et al. 1994). Additionally, Green Sturgeon are long-lived fish that feed on sediment-dwelling benthic organisms and can potentially bioaccumulate OCs for decades.

Previous monitoring studies on other sturgeon species frequently detected OCs in the tissues of sacrificed animals (Foster et al. 2001; Feist et al. 2005; Hosseini et al. 2008; Jacobs et al. 2014; Gundersen et al. 2017), and at least two studies have reported OCs in the plasma of sturgeon (Gundersen et al. 2008; Jacobs et al. 2014). These studies reported that DDE (the most stable degradation product of the 
pesticide DDT) was the most prevalent and concentrated OC in sturgeon. Plasma concentrations of DDE (non-detect to $10.6 \mathrm{ng} \mathrm{mL}^{-1}$ ) from the Green Sturgeon were similar to what was reported in plasma for White Sturgeon from the Pacific Northwest where the $\sum$ DDTs (lipid normalized) reached $150 \mathrm{ng} \mathrm{mL}^{-1}$ (Gundersen et al. 2008). Lake sturgeon from the Midwestern US had similar reported concentrations of DDE, ranging from 7.20 to $47.82 \mathrm{ng} \mathrm{mL}^{-1}$ (Jacobs et al. 2014). It should be noted that typically $\sum$ DDTs are reported; however, DDT and DDD were not detected in this study.

\section{Contaminant differences according to sex and maturity}

A sex-specific trend was not observed for copper, selenium, the $\sum_{16} \mathrm{Pest}$, and most individual OCs when all female and male fish were compared $(n=122)$. Some earlier sturgeon studies reported males with higher loads of persistent, bioaccumulative contaminants than females. A possible explanation is that, at reproductive maturity, females are able to release contaminants in their eggs lowering their overall body burden (Foster et al. 2001; Gundersen et al. 2017). In this study, four female fish were considered capable of spawing, but contaminant concentrations were not different $(p>0.05)$ than those of other female fish or the male fish, with one exception. Only a-BHC concentrations were significantly different $(p=0.038)$ between male and female fish. Plasma concentrations of a-BHC for males were $2.47+/-2.1 \mathrm{ng} \mathrm{mL}^{-1}$ and female plasma concentrations were $1.48+/-1.4 \mathrm{ng} \mathrm{mL}^{-1}$. The absence of sex-specific differences may also be explained by a sampled population skewed by more sub-adult fish (Gundersen et al. 2017) or the larger number of female fish $(n=98)$ compared to male fish $(n=24)$ included in this study, Fig. 3. P-values for all sex differences can be found in Table S5.

Fig. 3 Comparison of mean blood plasma contaminant concentrations (with standard deviation) between male and female fish for sub-adult and adult North American Green Sturgeon (sub-adult females $(n=66)$, sub-adult males $(n=1)$, adult females $(n=32)$, adult males $(n=23)$ ). No statistical differences $(p<0.05)$ were found.

\section{Contaminant differences according to site of catch and release}

With few exceptions, contaminants were statistically different according to location, Fig. 4. The greatest differences were for a-BHC and 4,4'-DDE. For a-BHC, Green Sturgeon caught in Grays Harbor had different plasma concentrations $\left(2.58+/-1.8 \mathrm{ng} \mathrm{mL}^{-1}, \mathrm{p}<0.001\right)$ than Green Sturgeon from the Columbia River $\left(1.45+/-1.5 \mathrm{ng} \mathrm{mL}^{-1}\right)$ and Willapa Bay $\left(0.957+/-0.66 \mathrm{ng} \mathrm{mL}^{-1}\right)$. The average 4,4'-DDE concentrations from the Columbia River plasma samples $\left(1.22+/-1.3 \mathrm{ng} \mathrm{mL}^{-1}\right)$ were the highest and different from Grays Harbor $\left(0.63+/-1.6 \mathrm{ng} \mathrm{mL}^{-1}\right)$ and Willapa Bay $\left(0.414+/-0.34 \mathrm{ng} \mathrm{mL}^{-1}\right)$. Aldrin, on the other hand, had similar concentrations as the Columbia River $\left(1.67+/-1.0 \mathrm{ng} \mathrm{mL}^{-1}\right)$ and Grays Harbor $(1.50+/-1.0 \mathrm{ng}$ $\mathrm{mL}^{-1}$, but were different than Willapa Bay $\left(1.02+/-0.58 \mathrm{ng} \mathrm{mL}^{-1}, \mathrm{p}<0.04\right)$. The $\sum_{16}$ Pest concentrations followed the same pattern as aldrin and were not statistically different in fish caught in Grays Harbor $\left(6.98+/-3.5 \mathrm{ng} \mathrm{mL}^{-1}\right)$ and the Columbia River $\left(6.67+/-7.3 \mathrm{ng} \mathrm{mL}^{-1}\right)$. The $\sum_{16}$ Pest for fish caught in Willapa Bay $\left(3.75+/-3.9 \mathrm{ng} \mathrm{mL}^{-1}\right)$ were statistically different $(\mathrm{p}<0.02)$. The only contaminant that did 
not differ according to location was copper (Fig. 4). The most discernible observation was that fish caught in Willapa Bay had the lowest contaminant concentrations. Willapa Bay is a conservation estuary, has fewer anthropogenic influences, and is home to small towns and several oyster beds. The Columbia River and Grays Harbor estuaries are highly urbanized with current and legacy point sources of contaminants (Johnson et al. 2007). Green Sturgeon are a highly migratory species that are known to move between Washington coastal estuaries at a high frequency during the summer months (Moser and Lindley 2007). If inter-estuary movement was significant, one might expect little difference in the contaminant levels between catch and release sites. However, given the observed concentration differences between sites, movements between estuaries (at least during the period of peak presence) are likely infrequent. The PIT tag recovery data are consistent with this (Langness et al. 2014). Contaminant concentrations in the sturgeon plasma are likely to reflect contamination from the local environment that bioaccumulated in their food over the very recent past. At least for lipophilic contaminants, it makes sense that Green Sturgeon from Willapa Bay had the lowest contaminant concentrations, given that is expected to have the lowest levels of environmental contamination (Johnson et al. 2007). Although it is possible that contaminants could be released into the blood after increased metabolism that may have resulted from disease or starvation (Keller et al. 2004), given the location and timing of the sampling, the explanation of site differences resulting from dietary exposure is more likely.

Similar site differences have been observed in studies using blood to monitor contaminants in several wildlife species. A very similar study on White Sturgeon found elevated levels of DDE from fish collected near the Bonneville Dam site in comparison to other locations from the Columbia River (Gundersen et al. 2008). Site-specific PCB congener profiles were found in the plasma of water snakes (Bishop and Rouse 2000) and snapping turtles (Dabrowska et al. 2006). Bucchia et al. (2015) found significantly higher concentrations of PCBs, OCs, and polycyclic aromatic hydrocarbons in the blood of loggerhead turtles collected from industrialized waters compared to the open ocean environment. Less research has been done on inorganic contaminants in wildlife plasma, and inorganics would not be expected to biomagnify like OCs and other persistent, bioaccumulative contaminants. In the present study, there were site differences for selenium in the Green Sturgeon, but not for copper. Bucchia et al. (2015) observed something similar in loggerhead turtles. Site-specific concentration differences were not observed for most metals ( $\mathrm{Cu}, \mathrm{As}, \mathrm{Pb}$ or $\mathrm{Cd})$, but they did find higher concentrations of zinc and mercury in the loggerhead turtles from industrialized waters (Bucchia et al. 2015). They did not report data for selenium. It is known that some toxic metals like mercury bioaccumulate in wildlife (Van De Merwe et al. 2010), and previous studies have indicated that selenium can bioaccumulate in protein-rich sturgeon tissues (Schwarz et al. 2006; Gundersen et al. 2017). Plasma monitoring may be an indicator of recent exposure for bioaccumulative metals, but maybe not for other metals. With so few studies on the monitoring of metals in wildlife plasma, it remains difficult to interpret the inconsistent trends. More research is needed.

One possible explanation for contaminant differences between estuaries could be differences in DPS compositions. In a previous study, Schreier et al. (2016) found that sDPS green sturgeon dominate collections from the Columbia River estuary and Willapa Bay, and that nDPS green sturgeon are more common in Grays Harbor than in the other two estuaries, during 2010-2012. However, the plasma 
samples used in this study were selected to provide adequate and mostly equal samples of fish from both DPSs from each estuary, and across all locations.

Fig. 4 Comparison of Green Sturgeon plasma contaminant concentrations according to the three sampling locations: Columbia River (CR), Willapa Bay (WB), and Grays Harbor (GH). Letters above bars indicate a significant difference when letters differ, ${ }^{*}=$ removed an outlier

\section{Contaminant differences between Green Sturgeon DPSs}

A main objective of this study was to compare contaminant concentrations between distinct populations segments of Green Sturgeon, the nDPS $(n=69)$ and the ESA-listed sDPS $(n=62)$. For all contaminants, only copper plasma concentrations differed by DPS $(p=0.04)$. The sDPS fish had slightly higher concentrations of plasma copper $\left(262+/-145 \mathrm{ng} \mathrm{mL}^{-1}\right)$ than nDPS fish $\left(216+/-100 \mathrm{ng} \mathrm{mL}^{-1}\right)$. Comparisons were also made amongst females and males according to DPS. No significant differences were found between nDPS male $(n=7)$ and female $(n=56)$ fish, but sDPS males $(n=17)$ had higher concentrations of copper $(p=0.001)$ and a-BHC $(0.028)$ compared to the female $(n=42)$ fish (Table S5).

Because there were notable site-specific differences (Fig. 4), contaminant loads in nDPS vs sDPS were compared according to site, Fig. 5. The sDPS samples collected from Grays Harbor had higher copper concentrations $(p=0.05)$ than nDPS samples from Grays Harbor. The a-BHC concentrations from fish caught in the Columbia River $(p=0.007)$ and Willapa Bay $(p=0.019)$ were also higher in sDPS fish. It is noteworthy that the highest concentrations of most contaminants ( $\alpha$ - and $\gamma-B H C, 4,4$ '-DDE, endosulfan II, endosulfan sulfate, PCB 180, PCB 194, PCB 194, Ar, Pb, and Se) were found in the ESA-listed sDPS fish. Accordingly, $\sum_{16}$ Pest and $\sum$ PCBs were also highest from sDPS fish. The only exceptions of an nDPS fish having higher individual contaminant concentrations were for $\mathrm{Cu}$, heptachlor, aldrin, methoxychlor, and PCB99.

Although the distinct population segments intermix in the open ocean and during feeding in the non-natal estuaries, they spawn and spend the first few years in freshwater, regionally separated by their natal rivers and estuaries. Most Green Sturgeon spawn in southern Oregon to northern California or central California for the nDPS and sDPS, respectively (Adams et al. 2007). The observed differences in contaminants may reflect long-term accumulation, given that the sDPS fish spawn and rear in watersheds with more urbanization and agriculture. It is also possible that the reduced sample size after separating the samples by DPS and location reduced the power of the analysis. Age (using size as a proxy) may also be a confounding factor, as older individuals would have had a longer amount of time to bioaccumulate contaminants. Southern DPS fish were larger on average $(p<0.001)$. The average fork lengths for the fish in this study were 138 and $118 \mathrm{~cm}$ for sDPS and nDPS, respectively. These DPS size averages and distributions closely matched those observed for all Green Sturgeon captured during the 2010-2012 tagging operations (Schreier et al. 2016). However, overall, the average contaminant concentrations were similar for the northern and southern distinct population segments. 
Fig. 5 Comparison of contaminant concentrations between northern and southern North American Green Sturgeon distinct population segments (DPSs) at each location, means with standard deviations for a) Columbia River (CR) nDPS fish ( $n=20)$ and sDPS fish $(n=24), b)$ Willapa Bay (WB) nDPS fish $(n=17)$ and sDPS fish ( $n=26), c)$ Grays Harbor (GH) nDPS fish ( $n=32)$ and sDPS fish $(n=12)$. Significant differences are indicated on the figure by inclusion of the p-value. All p-values can be found on Table $\mathbf{S} 6$

\section{Implications for toxicity}

Monitoring contaminant concentrations using non-lethal samples, such as blood plasma, limits toxicity assessments. However, the OCs included in the present study are highly lipophilic, and the presence of these analytes in blood suggests accumulation in fatty tissues such as the liver or gonads. Studies across several species have correlated the bioaccumulation of OC pesticides and PCBs in the blood to concentrations of the contaminants in tissues, a matrix for which toxicity thresholds are typically based. Results from polar bears (Bernhoft et al. 1997), several turtle species (Keller et al. 2004; Dabrowska et al. 2006; Van De Merwe et al. 2010; Bucchia et al. 2015) and, most importantly, White Sturgeon (Gundersen et al. 2008) indicate that monitoring OCs in blood is a viable non-lethal way to assess contaminant loads in the tissues. Some researchers have also demonstrated linear relationships in sea turtles between blood plasma and tissue concentrations for several metals (Van De Merwe et al. 2010). On the other hand, there are limited studies on the extrapolation of blood concentration to tissue concentrations in sturgeon, and some contaminants may not adhere to linear relationships, as was the case for some toxic metals and OCs in green sea turtles (Van De Merwe et al. 2010). Nonetheless, previous studies do provide a means to estimate tissue concentrations and to convert tissue concentration to plasma concentration, allowing comparisons to traditional toxicity benchmarks.

The average Green Sturgeon plasma concentrations were less than the estimated thresholds shown in Table 1. The $\sum 16$ Pest average $(\mathrm{n}=128)$ was $5.47 \mathrm{ng} \mathrm{mL}^{-1}$ with a standard deviation of $5.5 \mathrm{ng} \mathrm{mL}^{-1}$ and ranged from non-detect to $48.5 \mathrm{ng} \mathrm{mL}^{-1}$. Only two female fish (one sDPS fish from Willapa Bay and one nDPS fish from the Columbia River) exceeded the estimated threshold of $40.9 \mathrm{ng} \mathrm{mL}^{-1}$. The $\sum$ DDTs (only $4,4^{\prime}$-DDE in this study) ranged from non-detect to $10.6 \mathrm{ng} \mathrm{mL}^{-1}$ and averaged 1.05 (+/-) $1.4 \mathrm{ng} \mathrm{mL}^{-1}$ falling well below the threshold. OC contamination is typically associated with reproductive effects in wildlife, and the toxicity benchmarks for organochlorine pesticides refer to endocrine disruption from White Sturgeon (Feist et al. 2005). This data suggests that few Green Sturgeon had accumulated toxic levels of OCs. 


\begin{tabular}{|c|c|c|c|c|}
\hline \multicolumn{5}{|c|}{ Contaminant toxicity thresholds } \\
\hline Analyte & $\begin{array}{l}\text { Estimated threshold } \\
\text { plasma concentration } \\
\text { (ppb) }\end{array}$ & $\begin{array}{l}\text { Threshold } \\
\text { tissue } \\
\text { parameter }\end{array}$ & $\begin{array}{l}\text { Threshold tissue } \\
\text { concentration (ppm) }\end{array}$ & Reference \\
\hline$\sum_{16}$ Pesticides & $40.9 \mathrm{ng} \mathrm{mL}^{-1}$ & $\begin{array}{l}\text { Liver, White } \\
\text { Sturgeon }\end{array}$ & $5.6 \mu \mathrm{g} \mathrm{g}^{-1}$ lipid & $\begin{array}{l}\text { (Feist et } \\
\text { al. 2005) }\end{array}$ \\
\hline$\sum \mathrm{DDTs}$ & $48.9 \mathrm{ng} \mathrm{mL}^{-1}$ & $\begin{array}{l}\text { Liver, White } \\
\text { Sturgeon }\end{array}$ & $9.5 \mu \mathrm{g} \mathrm{g}^{-1}$ lipid & $\begin{array}{l}\text { (Feist et } \\
\text { al. 2005) }\end{array}$ \\
\hline
\end{tabular}

Table 1. Tissue thresholds were converted to plasma concentrations using regression equations from White Sturgeon liver correlations ( $\mu \mathrm{g} \mathrm{g}^{-1}$ lipid) for OCs according to Gundersen et al. (2017)

Other contaminants are not as easily adapted to tissue threshold concentrations. For instance, the copper data is remarkable but also challenging to interpret. Copper concentrations had a sizable range - four orders of magnitude - in the Green Sturgeon plasma. Toxicity studies have shown that sturgeon are particularly sensitive species of fish to waterborne copper (Ivey et al. 2019), although it is unclear if copper in green sturgeon plasma is derived from dietary uptake or uptake across the gills. Average selenium concentrations exhibited a narrower concentration range in the blood plasma (non-detect to 359 $\mathrm{ng} \mathrm{mL}^{-1}$ ), but at environmentally relevant concentrations, selenium can be a concern for all life stages of sturgeon (Linares-Casenave et al. 2015). Toxic effects of selenium in Green Sturgeon have been shown to range from death to endocrine disruption and include teratogenic effects through maternal transfer to the eggs (Silvestre et al. 2010). It is currently unknown how $\mathrm{Cu}$ and Se concentrations in the blood relate to tissue concentrations or environmental exposure concentrations. Future studies should study selenium and copper bioaccumulation and the plasma/tissue relationships in order to better understand the range of concentrations observed in the Green Sturgeon plasma. Additionally, all contaminants that where included in this study (10 metals, 16 OC pesticides, and 14 PCBs) have known toxic effects, but given the absence of toxicity benchmarks and the challenges of converting plasma to tissue concentrations, further toxicity interpretations are not appropriate. Lastly, how other contaminants (not included in this study) and mixtures of contaminants may affect sturgeon health and survival requires further study.

\section{Conclusions}

This is one of the first reports of contaminants in Green Sturgeon from the Pacific Northwestern United States. Non-lethal sampling provided an effective means to study contaminant exposure in the sturgeon. Parts per billion levels of OC pesticides, metals, and PCBs were found in the blood plasma of nDPS and ESA-listed sDPS Green Sturgeon caught in the Columbia River, Grays Harbor, and Willapa Bay. There were minimal differences between average contaminant loads for sDPS and nDPS Green Sturgeon or between the sexes. Feeding location may be a better indicator of contaminant loads. These data, in combination with tissue correlation studies, suggest that plasma could be used to assess tissue bioaccumulation for some contaminants, but maybe not for many metals, including copper. Few fish exceeded tissue-based 
toxicity thresholds; however, comparisons were made after correlating plasma to tissue concentrations. Chemical contamination as a contributing reason for population decline and a hinderance for recovery requires further investigation, including information on other contaminants or genetic differences in the susceptibility of contamination. Further work should address data gaps in the understanding of contaminant redistribution between blood and tissues for OCs and metals; and, plasma/tissue correlations. In order to strengthen the weight of evidence for toxicity assessments using non-lethal monitoring, future study could also report plasma toxicity threshold values or provide plasma to tissue correlations.

\section{Declarations}

Funding NOAA Fisheries - West Coast Region

Conflicts of interest/Competing interests Not applicable

Ethics approval Not applicable

Consent to participate Not applicable

Consent for publication Not applicable

Availability of data and material Not applicable

Code availability Not applicable

\section{Authors' contributions Not applicable for journal}

Electronic supplementary material (attachment)

Rights and permissions Not applicable

\section{Acknowledgements}

The authors would like thank Nathan Humphreys and Delaney Cyphers who performed the organic extractions and metals extractions. The study was funded by NOAA. The findings and conclusions in this article are those of the authors and do not necessarily represent the views of the U.S. Fish and Wildlife Service. Any use of trade, product, or firm names is for descriptive purposes only and does not imply endorsement by the U.S. Government.

\section{References}

Adams, PB, Grimes C, Hightower JE, Lindley ST, Moser ML, Parsley MJ (2007) Population status of North American Green Sturgeon, Acipenser medirostris. Environ Biol Fish 79:339-356. 
Adams PB, Grimes C, Hightower JE, et al (2002) Status review for North American green sturgeon, Acipenser medirostris. NOAA. https://www.fisheries.noaa.gov/resource/document/status-review-northamerican-green-sturgeon-acipenser-medirostris Accessed 10 Jan 2021

Anderson EC, Ng TC, Crandall ED, Garza JC (2017) Genetic and individual assignment of tetraploid green sturgeon with SNP assay data. Conserv Genet 18:1119-1130. https://doi.org/10.1007/s10592-017-09635

Bernhoft A, Wiig O, Janneche \&, Skaare U (1997) Organochlorines in polar bears (Ursus maritimus) at Svalbard. Environ Pollut 95:159-175

Bishop CA, Rouse JD (2000) Chlorinated Hydrocarbon Concentrations in Plasma of the Lake Erie Water Snake (Nerodia sipedon insularum) and Northern Water Snake (Nerodia sipedon sipedon) from the Great Lakes Basin in 1998 Environmental Contamination a n d Toxicology. Environ Contam Toxicol 39:500505. https://doi.org/10.1007/s002440010133

Bucchia M, Camacho M, Santos MRD, et al (2015) Plasma levels of pollutants are much higher in loggerhead turtle populations from the Adriatic Sea than in those from open waters (Eastern Atlantic Ocean). Sci Total Environ 523:161-169. https://doi.org/10.1016/j.scitotenv.2015.03.047

Dabrowska H, Fisher SW, Estenik J, et al (2006) Polychlorinated Biphenyl Concentrations, Congener Profiles, and Ratios in the Fat Tissue, Eggs, and Plasma of Snapping Turtles (Chelydra s. serpentina) from the Ohio Basin of Lake Erie, USA. Arch Environ Contam Toxicol 51:270-286.

https://doi.org/10.1007/s00244-005-0113-9

Dhananjayan V, Muralidharan S (2010) Levels of Organochlorine Pesticide Residues in Blood Plasma of Various Species of Birds from India. Bull Environ Contam Toxicol 85:129-136.

https://doi.org/10.1007/s00128-010-0045-6

Doukakis P (2014) Informal status review for the Northern Distinct Population Segment of North American green sturgeon, Protected Resource Division, West Coast Region, NOAA Fisheries https://www.fisheries.noaa.gov/resource/document/2014-informal-status-review-northern-distinctpopulation-segment-north-american Accessed 10 Jan 2021

Dumbauld BR, Holden DL, Langness OP (2008) Do sturgeon limit burrowing shrimp populations in Pacific Northwest estuaries? Environ Biol Fishes 83:283-296. https://doi.org/10.1007/s10641-008-9333-y

Elliott JE, Shutt L (1993) Monitoring organochlorines in blood of sharp-shinned hawks ( Accipiter striatus ) migrating through the great lakes. Environ Toxicol Chem 12:241-250.

https://doi.org/10.1002/etc.5620120207

Feist G, Schreck CB, Fitzpatrick MS, Redding JM (1990) Sex steroid profiles of coho salmon (Oncorhynchus kisutch) during early development and sexual differentiation. Gen Comp Endocrinol 
Feist GW, Webb MAH, Gundersen DT, et al (2005) Evidence of detrimental effects of environmental contaminants on growth and reproductive physiology of white sturgeon in impounded areas of the Columbia River. Environ Health Perspect 113:1675-1682. https://doi.org/10.1289/ehp.8072

Fitzpatrick MS, Redding JM, Ratti FD, Schreck CB (1987) Plasma Testosterone Concentration Predicts the Ovulatory Response of Coho Salmon ( Oncorhynchus kisutch) to Gonadotropin-Releasing Hormone Analog. Can J Fish Aquat Sci 44:1351-1357. https://doi.org/10.1139/f87-160

Fitzpatrick MS, Van Der Kraak G, Schreck CB (1986) Profiles of plasma sex steroids and gonadotropin in coho salmon, Oncorhynchus kisutch, during final maturation. Gen Comp Endocrinol 62:437-451. https://doi.org/10.1016/0016-6480(86)90054-7

Farr, RA, Kern JC (2005) Green sturgeon population characteristics in Oregon. Final Progress Report Fish Research Project Oregon. Project number F-178-R. Oregon Department of Fish and Wildlife, Clackamas, Oregon. https://www.dfw.state.or.us/fish/oscrp/cri/docs/GSTG\%202005.pdf Accessed 10 Jan 2021

Foster EP, Fitzpatrick MS, Feist GW, et al (2001) Plasma Androgen Correlation, EROD Induction, Reduced Condition Factor, and the Occurrence of Organochlorine Pollutants in Reproductively Immature White Sturgeon (Acipenser transmontanus) from the Columbia River, USA. Arch Environ Contam Toxicol 41:182-191. https://doi.org/10.1007/s002440010236

Gundersen DT, Webb MAH, Fink AK, et al (2008) Using blood plasma for monitoring organochlorine contaminants in juvenile white sturgeon, Acipenser transmontanus, from the lower Columbia River. Bull Environ Contam Toxicol 81:225-229. https://doi.org/10.1007/s00128-008-9417-6

Gundersen DT, Zeug SC, Robert, et al (2017) Tissue Contaminant Burdens in San Francisco Estuary White Sturgeon (Acipenser transmontanus): Implications for Population Recovery. Arch Environ Contam Toxicol 73:334-347. https://doi.org/10.1007/s00244-017-0378-9

Hosseini SV, Dahmardeh Behrooz R, Esmaili-Sari A, et al (2008) Contamination by organochlorine compounds in the edible tissue of four sturgeon species from the Caspian Sea (Iran). Chemosphere 73:972-979 https://doi.org/10.1016/j.chemosphere.2008.06.036

Israel JA, Bando KJ, Anderson EC, May B (2009) Polyploid microsatellite data reveal stock complexity among estuarine North American green sturgeon. Can J Fish Aquat Sci 66:1491-1504

Ivey CD, Besser JM, Steevens JA, et al (2019) Influence of Dissolved Organic Carbon on the Acute Toxicity of Copper and Zinc to White Sturgeon (Acipenser transmontanus) and a Cladoceran (Ceriodaphnia dubia). Environ Toxicol Chem 38:2682-2687. https://doi.org/10.1002/etc.4592 
Jacobs GR, Gundersen DT, Webb MAH, et al (2014) Evaluation of organochlorine pesticides and sex steroids in lower Niagara river lake Sturgeon. J Fish Wildl Manag 5:109-117.

https://doi.org/10.3996/072013-JFWM-048

Johnson LL, Ylitalo GM, Arkoosh MR, et al (2007) Contaminant exposure in outmigrant juvenile salmon from Pacific Northwest estuaries of the United States. Environ Monit Assess 124:167-194.

https://doi.org/10.1007/s10661-006-9216-7

Kahn J, Morhead M (2010) A protocol for use of Shortnose, Atlantic, Gulf, and Green Surgeons. U.S. Dep. Commerce, NOAA Tech. Memo. NMFS-OPR-45

https://www.fisheries.noaa.gov/resource/document/protocol-use-shortnose-atlantic-gulf-and-greensturgeons Accessed on 10 Jan 2021

Keller JM, Kucklick JR, Harms CA, Mcclellan-green PD (2004) Organochlorine contaminants in sea turtles: Correlations between whole blood and fat. Environ Toxicol Chem 23:726-738

Langness OP (2007) Risk assessment of green sturgeon in Washington. Final report to USFWS Federal Aid Portland, Oregon. State Wildlife Grant FY02-T-1-4.

Langness OP, Dionne PE, Wageman CW, et al. (2014) Report A, Green sturgeon distribution and abundance in Washington and Oregon coastal estuaries. In: Mallette C (ed) Stud. green sturgeon West Coast United States. NOAA Fisheries Protected Species Conservation and Recovery Grant Number NA10NMF4720037 Project Completion Report., p 144

Linares-Casenave J, Linville R, Van Eenennaam JP, et al (2015) Selenium tissue burden compartmentalization in resident white sturgeon (Acipenser transmontanus) of the San Francisco Bay Delta estuary. Environ Toxicol Chem 34:152-160. https://doi.org/10.1002/etc.2775

Lindley ST, Erickson DL, Moser ML, et al (2011) Electronic tagging of green sturgeon reveals population structure and movement among estuaries. Trans Am Fish Soc 140:108-122. https://doi.org/10.1080/00028487.2011.557017

Lindley ST, Moser ML, Erickson DL, Belchick M, Welch DW, Rechisky E, Kelly JT, Heublein J, Klimley AP (2008) Marine migration of north American green sturgeon. Trans Am Fish Soc 137:182-194

Moser ML, Israel JA, Neuman M, et al (2016) Biology and life history of green sturgeon (Acipenser medirostris ayres, 1854): State of the science. J Appl Ichthyol 32:67-86.

https://doi.org/10.1111/jai.13238

Moser ML, Lindley ST (2007) Use of Washington estuaries by subadult and adult green sturgeon. Environ Biol Fishes 79:243-253. https://doi.org/10.1007/s10641-006-9028-1

Moser ML, Patten K, Corbett SC, Feist BE, Lindley ST (2017) Abundance and distribution of sturgeon feeding pits in a Washington estuary. Environ Biol Fishes 100:597-609. https://doi.org/10.1007/s10641- 
NOAA/Fisheries Green Sturgeon. https://www.fisheries.noaa.gov/species/green-sturgeon. Accessed 2 Oct 2020

Schwarz MS, Lydick CD, Tillitt DE, Papoulias, DM, Gross TS (2006) A health risk evaluation for pallid sturgeon (Scaphirhynchus albus) in the lower Platte River using shovelnose sturgeon (Scaphirhynchus platorynchus) as a surrogate: U.S. Fish and Wildlife Service, Division of Environmental Quality, Region 6, final Report, Grand Island, Nebr., 105 p.

Schreier A, Langness OP, Israel JA, Van Dyke E (2016) Further investigation of green sturgeon (Acipenser medirostris) distinct population segment composition in non-natal estuaries and preliminary evidence of Columbia River spawning. Environ Biol Fish 99:1021-1032. https://doi.org/10.1007/s10641-016-0538-1

Schreier A, Stevens P (2020) Further evidence for lower Columbia River green sturgeon spawning. Environ Biol Fish 103:201-208. https://doi.org/10.1007/s10641-019-00945-9

Silvestre F, Linares-Casenave J, Doroshov SI, Kültz D (2010) A proteomic analysis of green and white sturgeon larvae exposed to heat stress and selenium. Sci Total Environ 408:3176-3188. https://doi.org/10.1016/j.scitotenv.2010.04.005

Stillwater Sciences, Wiyot Tribe Natural Resources Department (2017) Status, distribution, and population of origin of green sturgeon in the Eel River: results of 2014-2016 studies. Prepared by Stillwater Sciences, Arcata, California and Wiyot Tribe, Natural Resources Department, Loleta, California, for National Oceanic and Atmospheric Administration, Fisheries Species Recovery Grants to Tribes, Silver Springs, Maryland. https://www.wiyot.us/DocumentCenter/View/126/Eel-River-Green-Sturgeon-Final-Report-PDF?bidld= Accessed 10 Jan 2021

Tanabe S, Iwata H, Tatsukawa R (1994) Global contamination by persistent organochlorines and their ecotoxicological impact on marine mammals. Sci Total Environ 154:163-177. https://doi.org/10.1016/0048-9697(94)90086-8

Van De Merwe JP, Hodge M, Olszowy HA, et al (2010) Using blood samples to estimate persistent organic pollutants and metals in green sea turtles (Chelonia mydas). Mar Pollut Bull 60:579-588. https://doi.org/10.1016/j.marpolbul.2009.11.006

Vardy DW, Doering JA, Santore R, et al (2015) Toxicity of Metals Associated with Sediments from the Columbia River to Early Life Stages of White Sturgeon. J Environ Anal Toxicol 05:262 https://doi.org/10.4172/2161-0525.1000262

Webb MAH, Erickson DL (2007) Reproductive structure of the adult green sturgeon, Acipenser medirostris, population in the Rogue River, Oregon. Environ Biol Fishes 79:305-314. https://doi.org/10.1007/s10641006-9061-0 
Webb M, Talbott M (2007) Gonadal histology and plasma steroid analyses from green sturgeon captured in Grays Harbor, Willapa Bay, and the Columbia River in 2003, 2004, and 2005. Report to Washington Department of Fish and Wildlife, 15 pp.

\section{Figures}

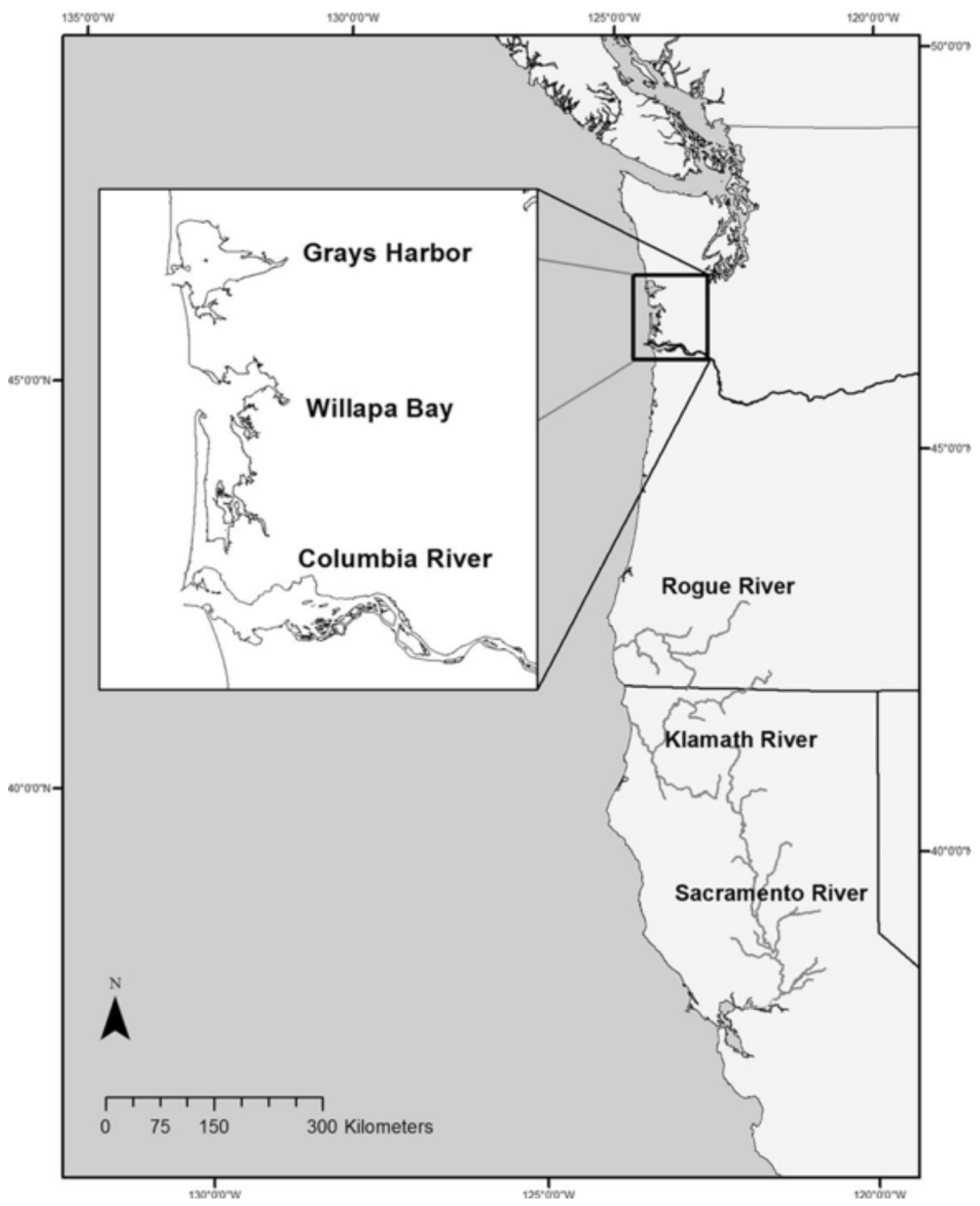

Figure 1 
Map of North American green sturgeon natal rivers showing the Sacramento River where the Southern Distinct Population Segment (SDPS) sturgeon spawn, and the Klamath and Rogue rivers where the Northern Distinct Population Segment (NDPS) sturgeon primarily spawn. The insert map shows the study area (Grays Harbor, Willapa Bay, and the Columbia River estuary) where the sampled Green Sturgeon were caught and released. Note: The designations employed and the presentation of the material on this map do not imply the expression of any opinion whatsoever on the part of Research Square concerning the legal status of any country, territory, city or area or of its authorities, or concerning the delimitation of its frontiers or boundaries. This map has been provided by the authors. 


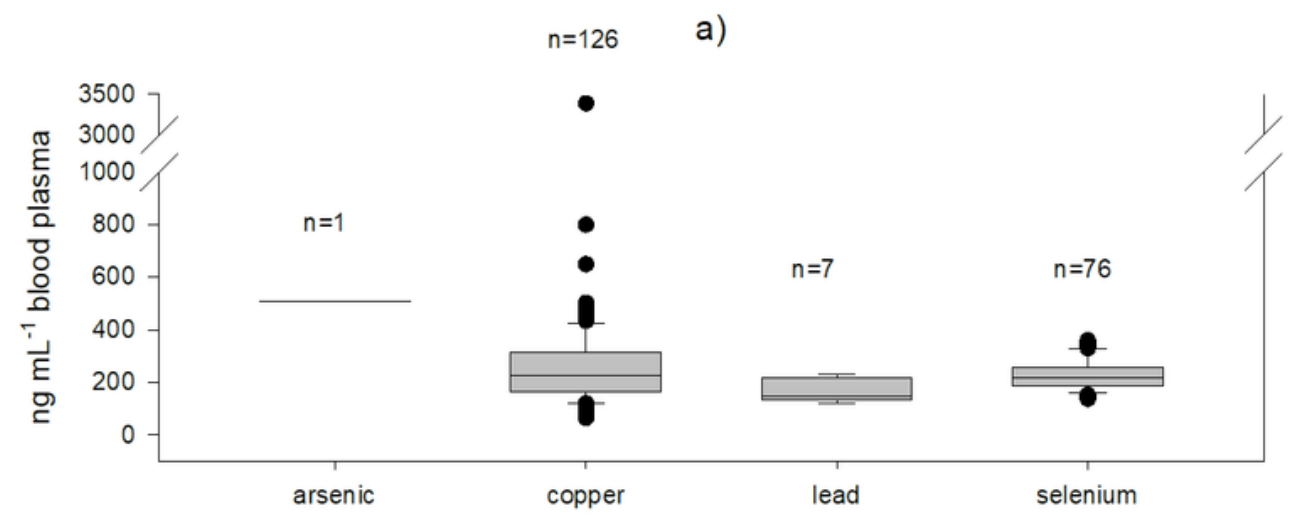

b)

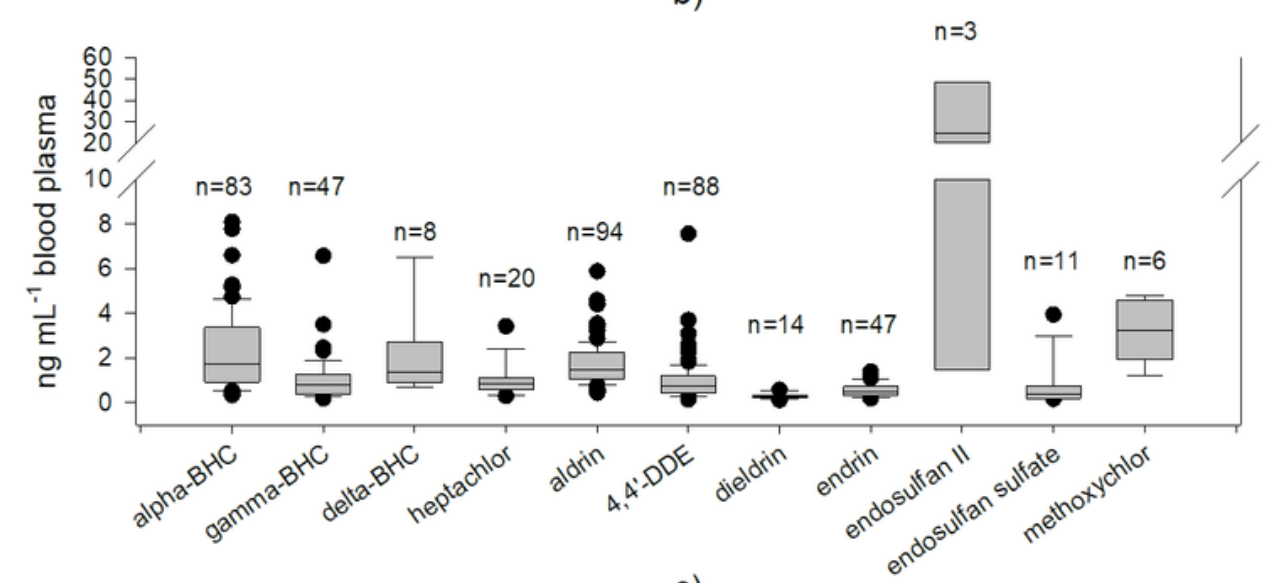

c)

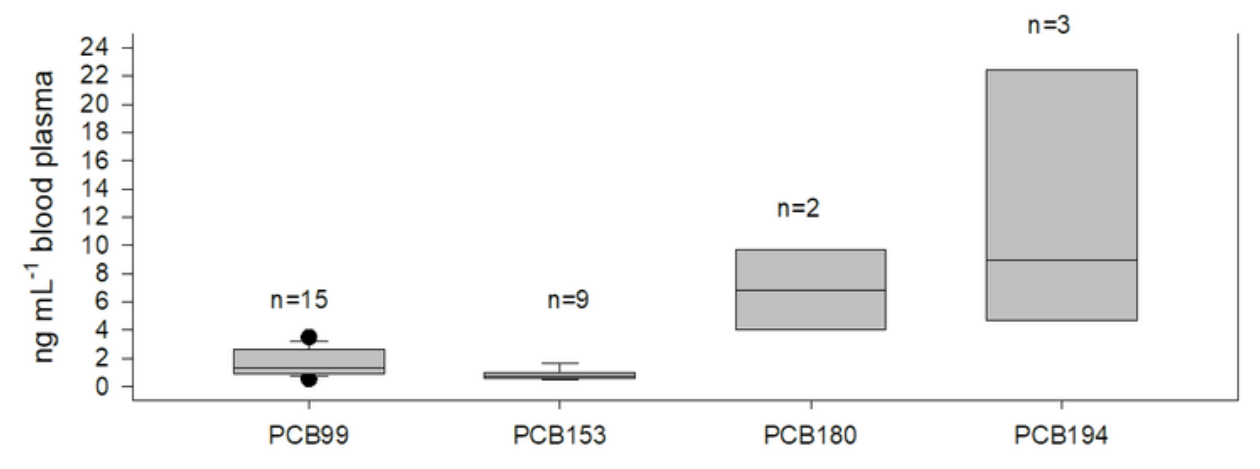

\section{Figure 2}

Distribution plots showing the range of concentrations and number of detections for a) metals, b) organochlorine pesticides, and c) polychlorinated biphenyls detected in the North American Green Sturgeon blood plasma. Boxes represent the 25th to 75th quartiles with the median shown as a horizontal line and outliers as dots 

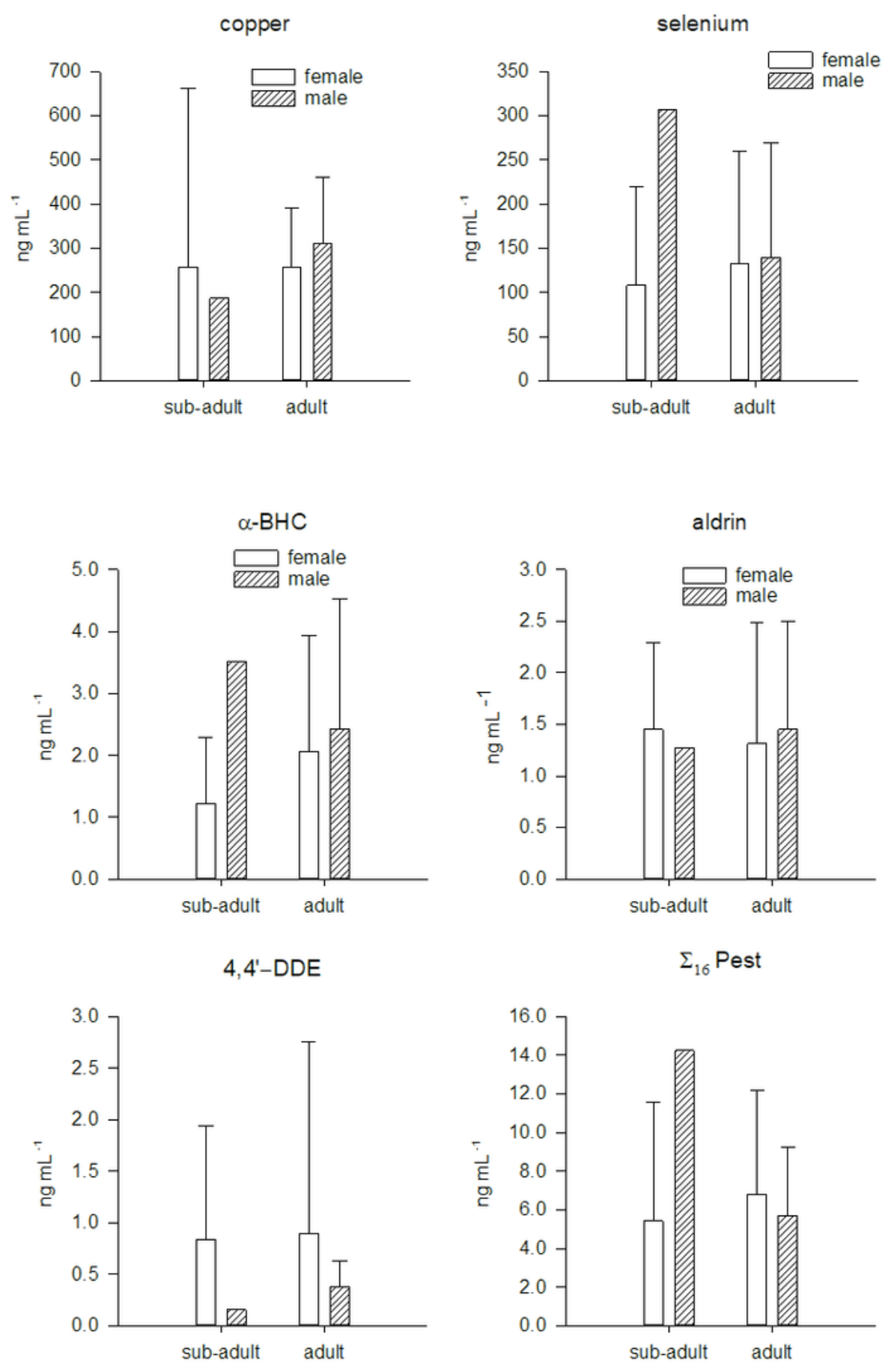

\section{Figure 3}

Comparison of mean blood plasma contaminant concentrations (with standard deviation) between male and female fish for sub-adult and adult North American Green Sturgeon (sub-adult females ( $n=66)$, subadult males $(n=1)$, adult females $(n=32)$, adult males $(n=23)$ ). No statistical differences $(p<0.05)$ were found. 

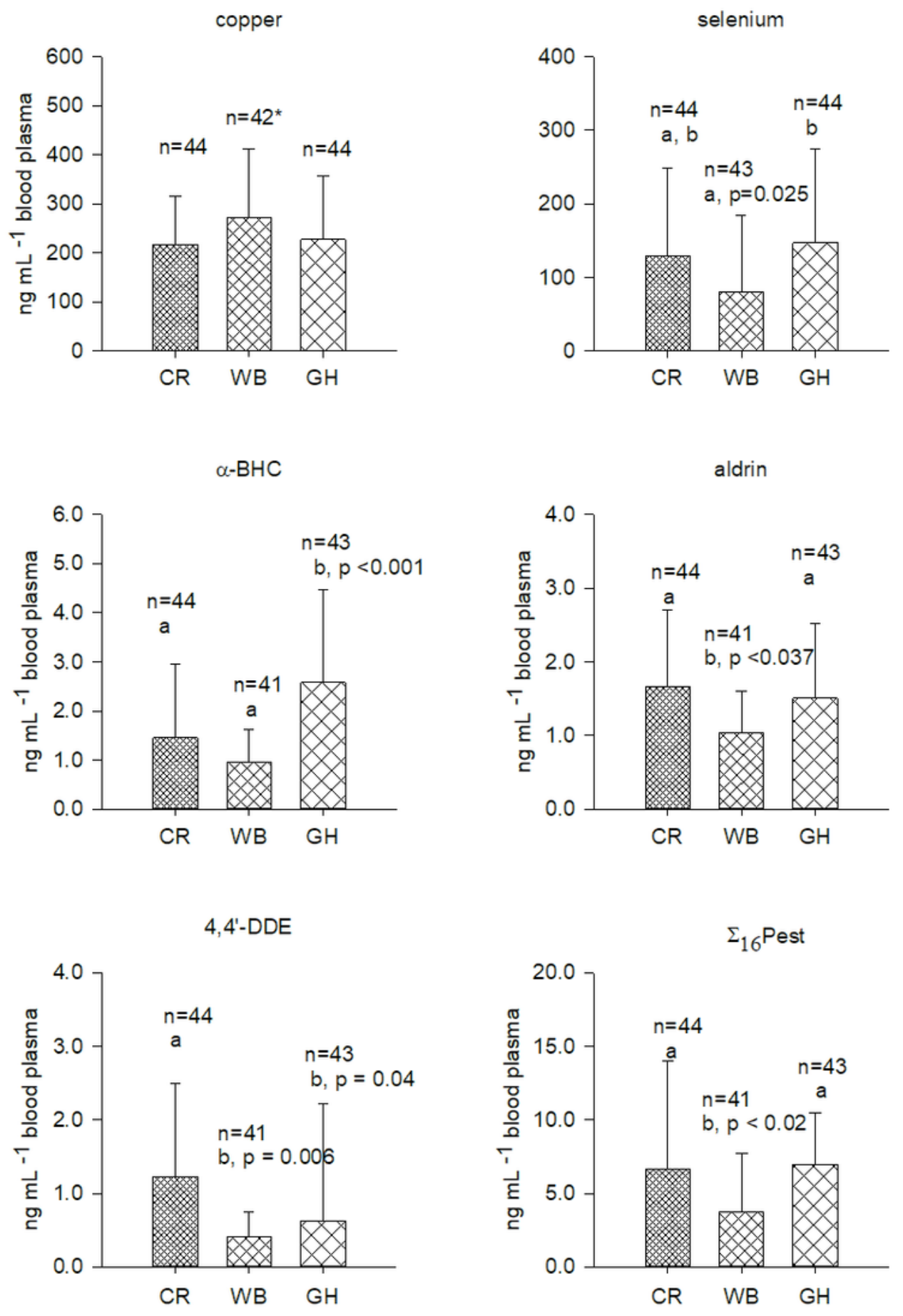

\section{Figure 4}

Comparison of Green Sturgeon plasma contaminant concentrations according to the three sampling locations: Columbia River (CR), Willapa Bay (WB), and Grays Harbor (GH). Letters above bars indicate a significant difference when letters differ, * ${ }^{*}$ removed an outlier 


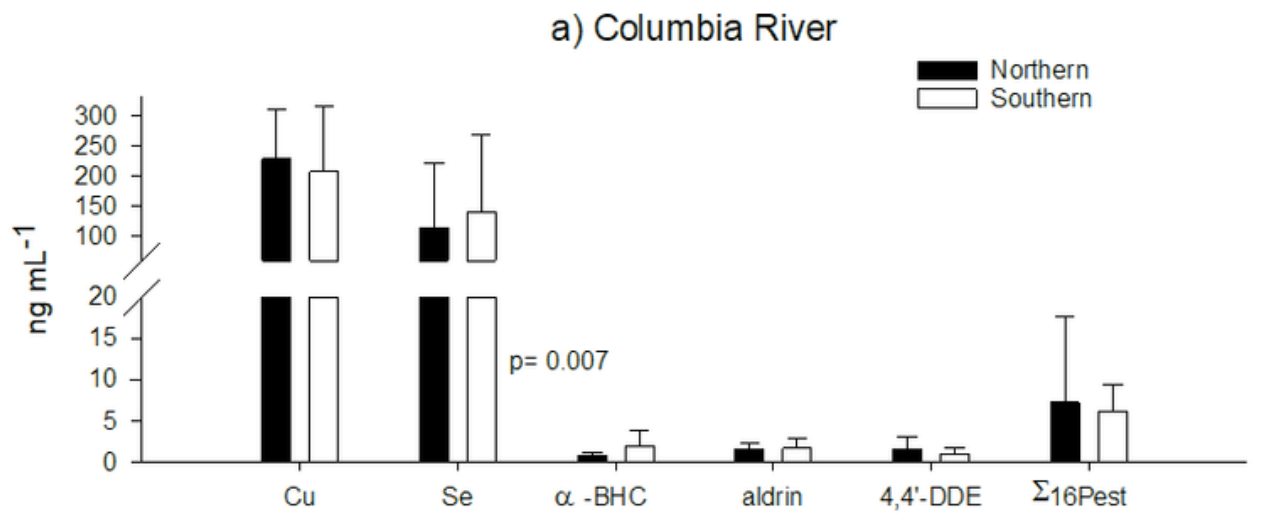

b) Willapa Bay

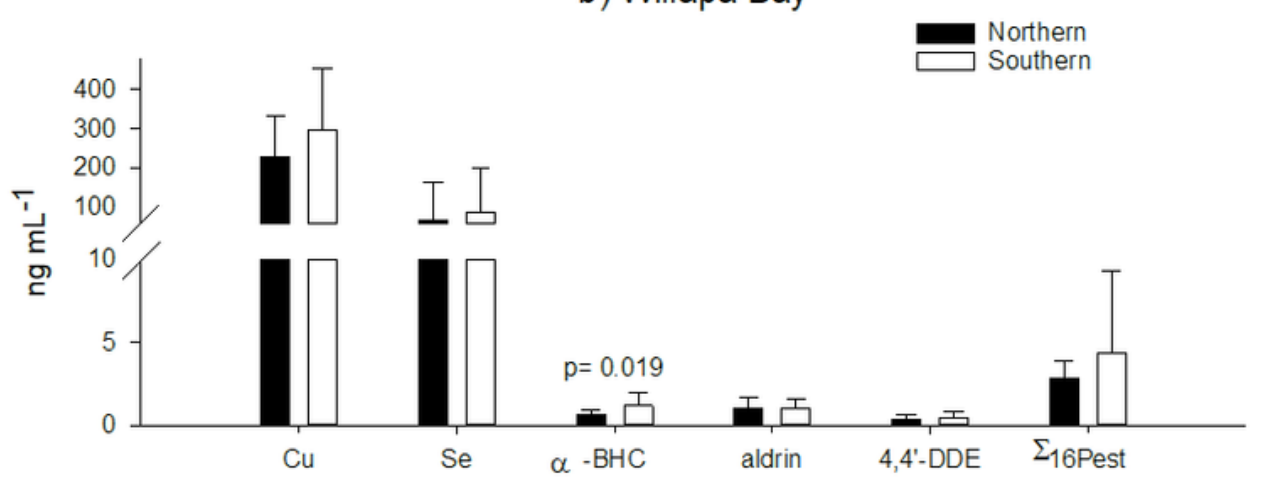

c) Grays Harbor

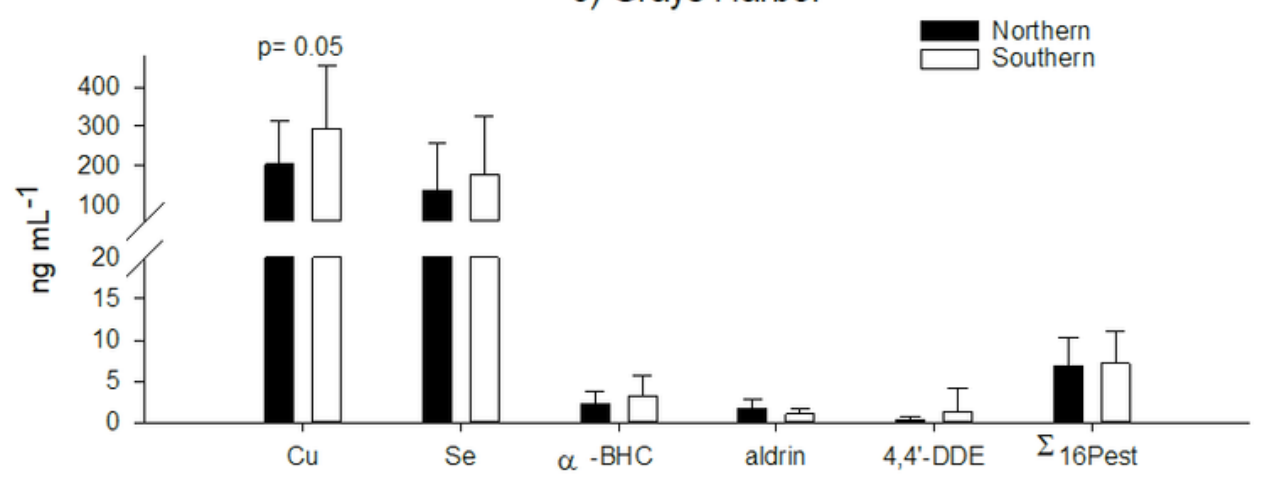

\section{Figure 5}

Comparison of contaminant concentrations between northern and southern North American Green Sturgeon distinct population segments (DPSs) at each location, means with standard deviations for a) Columbia River (CR) nDPS fish ( $n=20)$ and sDPS fish ( $n=24), b)$ Willapa Bay (WB) nDPS fish $(n=17)$ and sDPS fish ( $n=26), c)$ Grays Harbor (GH) nDPS fish $(n=32)$ and sDPS fish $(n=12)$. Significant differences are indicated on the figure by inclusion of the p-value. All p-values can be found on Table S6 